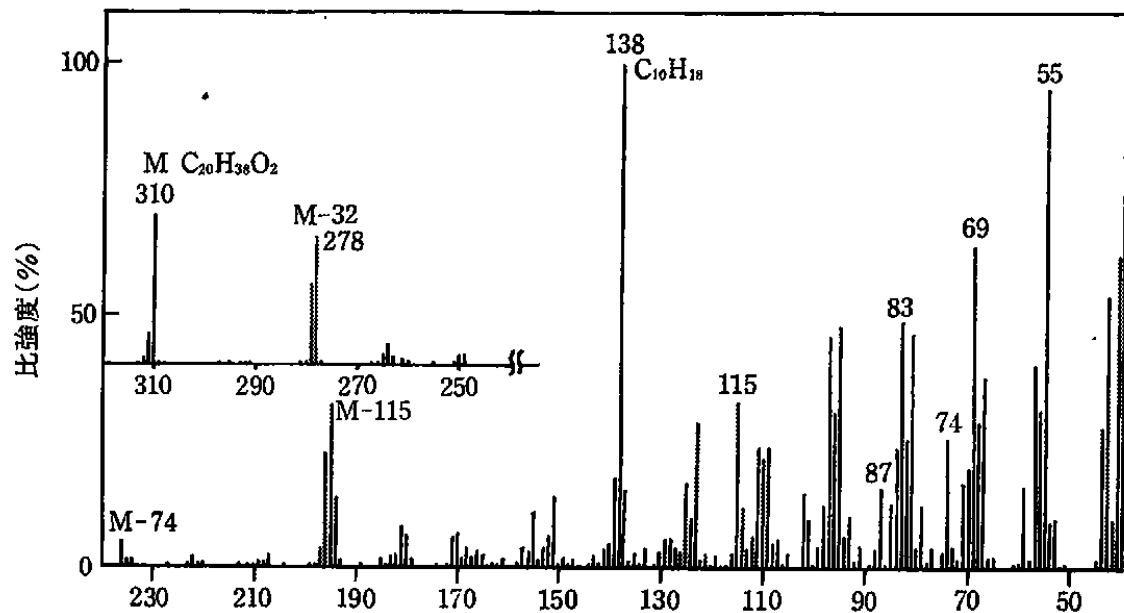

図1ミミズ末確慗成分不站和 $\mathrm{C}_{19}$ 脂肪酸メチルメステルの䆓量分析スペクトル $\therefore n-\mathrm{C}_{18}, n-\mathrm{C}_{19}\left(\right.$ 抢そらく $n-\mathrm{C}_{17}$ も) エ、ネテルの混在が認められた。

以上の飽和脂肪酸以外飞, 高質量側では $m / e=138$ (ベースピーク)および $m / \epsilon=M-$ 115 に大きなピークを示し，低賈量僋では 不餙和脂肪酸メチルエステルの筫量分析パ ターンの特徵をそなえた成分（困 1 )が単離 された。親ピークの質量から，不能和度 1 の脂肪酸であり, 分枝のある炭素数 19 不 飽和脂肪酸のメチルエステルであろうと推 定されたが，微量のためその構造を確定す るにはいたらなかった。同様の值量分析ス ペクトルを与える炭素数 17 の不飽和脂肪 酸のメチルエステルもきわめて少量ながら 単離された。
い $n$-脂肪酸エステルが少量混在していることが, 質量分析パタ ーンによって判明した。たとえば iso- $\mathrm{C}_{17}$ エステルには少量の
終りにNMRの潎定をしていただいた大阪大学理学部の方々に 感謝する。

\title{
ハロゲン化脂肪族岸化水秦から第一アミンの新しい合成法
}

\author{
（昭和 41 年 2 月 4 日受理）
}

長 沢㳯夫兆野尚男・福 井謙一*1

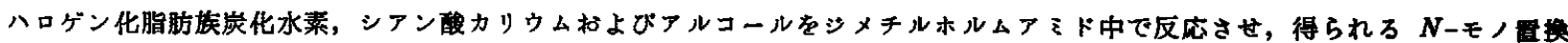
カルバミン酸エステルを塩酸で加水分解するととにより第一脂肪族アミンを合成する新しい方法について研究した。ハロゲン化脶 肪族炭化水素として臭化一nーブチルを選び，数種のアルコール(エチルアルコール，nーブチルアルコール，ベンシルアルコールお

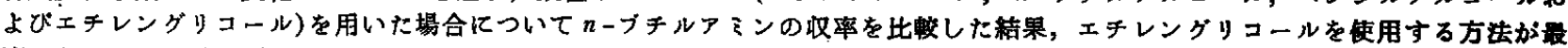

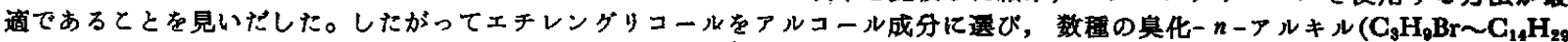
Br)，ハロゲン化アリル拈よ゙塩化ベンシルを原料として本法を試みたととろ，65９1\%の取率で第二アミンを含まない相当する 第一アミンを合成し得ることが確かめられた。ただし臬化ーงーアルキルを用いる埸合の第一アミン収率はかなり低い值(34〜40\%) しか得られなかった。

\section{1 緒 亭}

ハロゲン化脂肪族炭化水素を原料として第一アミンを合成する 方法としては Gabriel 反応りもしくは Delépine 反応2が広く用い られる。ぬたイソシアン酸エステルを中間体とする Hofmanns), (Curtius) および Lossens)の各反応とくに Hofmann 反応は, 純

* I Atsuo Nagasawa, Hisao Kitano, Kenichi Fukur 京 都大学工学部然料化学教室, 京都市左京区声田本町

1) S. Gabriel, Ber., 20, 2224(1887); R. B. Wagner, H. D. Zook, "Synthetic Organic Chemistry", John Wiley \& Sons, Inc.(1953)p. 674.

2) M. Delepine, Compt. rend., 120, 501(1895); R. B. Wagner, H. D. Zook, "Synthetic Organic Chemistry ", John Wiley \& Sons, Inc.(1953)p. 670.

3) A. W. Hofmann, Ber., 15, 407, 762(1882); E. S. Wallis, J. F. Lane, "Organic Ceactions", (1946) Vol. 3, 267.

4) T. Curtius, J. prakt. Chem., [ 2 ]50, 275(1894); P. A. S. Smith, "Organic Reactions" (1946) Vol. 3, 337.

5) W. Lossen, Ann., 161, 347(1872); H. L. Yale, Chem. Revs., 35, 209(1943).
粋な第一アミンを得る目的でしばしば用いられるが，これらの反 応を経由する方法では必然的に原料とする脂肪酸より炭秦数の1 個少ない第一アミンを生成することになる。Curtius 枟位を経る 方法においてはイソシアン酸エステルを直接加水分解してアミン を得るほかに, いったんジアルキル尿素または $N$-アルキルカル バミン酸エステルに誘導しこれを加水分解する方法もしばしば用 いられるが，多くの場合目的物の収率は低い。これを改善する目

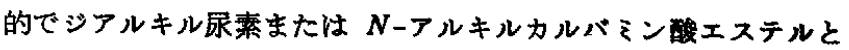
無水フタル酸とを反応させ，ついで Gabriel 反応と同様の方法で 第一アミンを得ることも行なわれている6)。また最近 Bachman? が Lossen 転位を経由する方法を改良して,ヒドロキシルアミン, 脂肪酸エステルおよび塩化ベンゾイルの縮合物あるいはヒドロキ シルアミンーーースルホンと脂肪酸との摍合物を分解して第一アミ ンを得る方法を発表しているが，この方法は脂肪族アミンをつく るためよりもむしろ芳香族酸から第一芳香族ア ミンを合成する方 法として適しているものである。

6) R. H. F. Manske, J. Am. Chem. Soc, 51, 1202(1929).

7) G. B. Bachman, J. Org. Chem., 29, 2576(1964). 
著者ら゙ははさにハロゲン化アルキルとシアン酸カリウムとを シメチルホルムアミド中でアルコールの存在に打いて反応させ, 好収率で $N$-アルキルカルバミン酸エステルを合成する方法につ いて報告したが，さらにとの反応を第一脂肪族ア ミンの選択的合 成に直接応用する方法について研究を行なった。

この方法によってハロゲン化アルキルからカルバミン酸エステ ルを合成する際，イソシアヌル酸トリアルキル，パラバン酸ジア ルキル，1,3-ジアルキル尿素などが副生する。そこでまずこれら のイソシアン酸誘導体について, その酸性媒体中に沶ける加水分 解反応を試みたところ，その加水分解の容易さは $N$-アルキルカ ルバミン酸エステル>1,3-シアルキル尿素>パラバン酸ジルキ ル>イソシアヌル酸トリアルキルの順であること，および加水分

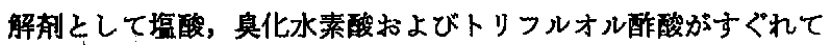
いることなどの事実を認めた。この予備実験の結果を参照し，八 ロゲン化アルキルから第一アミンの原料である $N$-アルキルカル バミン酸エステルを合成する際にイソシアヌル酸トリアルキルの 副生量ができるだけ少なくなるような条件，および加水分解とし て塩酸が用いられるような条件に重点を置いて実験を行なった。

八ロゲン化脂肪族炭化水素から第一アミンを得る合成法㹥つぎ の反応 (1)および(2)の2段階を経て行なわれる。

$$
\begin{aligned}
& \mathrm{RX}+\mathrm{R}^{\prime} \mathrm{OH}+\mathrm{KOCN} \\
& \stackrel{\mathrm{HCON}\left(\mathrm{CH}_{3}\right)_{2}}{\longrightarrow} \mathrm{RNHCO}_{2} \mathrm{R}^{\prime}+\mathrm{K} \\
& \stackrel{\mathrm{RNHCO}}{\mathrm{HCl}} \mathrm{R}^{\prime}+\mathrm{H}_{2} \mathrm{O} \\
& \stackrel{\mathrm{RNH}}{\longrightarrow}+\mathrm{R}^{\prime} \mathrm{OH}+\mathrm{CO}_{2}
\end{aligned}
$$

反応(1)において，アルコールとしてェチルアルコール，nブチルアルコール, ベンシルアルコールおよびエチレングリコー ルを用い，八ロゲン化脂肪族炭化水素の例として具化- $n$-ブチル を選びシシアン酸カリウムととむにシメチルホルムアミド中で反 応させた結果，アルコールを真化- $n$ ーブチルの $4 \mathrm{~mol}$ 倍(エチレ ングリコールのときには $2 \mathrm{~mol}$ 倍)使用すれば, 80〜89\% の収率 で $N-n$-ブチルカルバミン酸エステルを生成することが見いだ された。エチレングリコールを使用した場合には $N$ ー $ー$ ーブチル カルバミン酸のエチレングリコールモノエステルおよびジェステ ルの両者を生成物として得るが，これらはともに第一アミンの原 料として用いることができる。

ついで反応(1)によって得た各カルバミン酸エステルを $20 \%$ 堤酸により加水分解させた結果， $N-n$-ブチルカルバミン酸のエ チレングリコールモノエステルから 91\% の収率で $n$-ブチルア ミンが得られ, 以下ェチレングリコールのジェステル， $N-n-フ ゙$ チルカルバミン酸のエチルエステル, ベンジルエステル, $n$-ブチ ルエステルの順に酸加水分解の速度が低下することが明らかにな った。また $N-n$-ブチルカルバミン酸ベンジルを塩化水素を含 む米酿酸中で分解すると, 塩化水菜水溶液中の約 2 倍近くの収率 $(82 \%)$ で $n$-プチルアミンが得られることもかかった。

上記の第一ア 氵ンの合成法においては，反応によって生成した カルパミン酸エステルをいったん精倣したのち，これを分解に付 したが，さらに実際的な意味で興味あるつぎの事実が明らかにさ れた。すなわち十分精製したハロゲン化アルキル, シアン酸カリ ウム,エチレングリコールおよびジメチルルムムマドを使用し

8) A. Nagasawa, H. Kitano, K. Fukui, Bull. Japan Petr. Inst., 6, 72(1964).
て反応 (1)を行ない，反応混合物から単に無機塩および溶抄を除 去した残りの混合物(主としてNーアルキルカルバミン酸エステル からなる)をそのまま酸加水分解するこによって好取率で純粋な 第一アミンが直接的に合成される。

この方法により，アルコールとしてエチレングリコールを用い て各種の臭化一 $n$ ーアルキル $\left(\mathrm{C}_{3} \sim \mathrm{C}_{14}\right)$ から相当する $n$-アルキル アミンを 67〜91\% の段率で得た。また八ロゲン化アリルおよび 塩化ベンジルがらも相当する第一アミンが好収率で得られた。臭

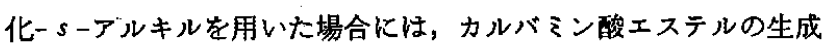
段階で副生物としてィソシアヌル酸エステルおよびオレフィンが 多量に生成し，また加水分解の際にもオレフィンの副生が認めら れ，との結果第一アミンの収率は 34〜40\% に低下した。

以上のようにこの第一ア゙ ミンの合成法はハロゲン化ーnーアルキ ル,アリルおよびベンジルを原料とする場合には，八ロゲン化脂 肪族炭化水慗を原料とする従来法ならびにイソシアン酸エステル を中間体とする他の諸方法にくらべて操作が簡単で目的物の収率 が良好であり，実験室的な第一脂肪族アミンの一般的合成法とし ての資格をむつことが認められた。

\section{2 実験}

\section{$2.1 N-n$-ブチルカルバミン酸エチル}

搝化一nーブチル $54.8 \mathrm{~g}(0.4 \mathrm{~mol})$, シアン酸カリウム8) $48.6 \mathrm{~g}$ $(0.6 \mathrm{~mol})$, エチルアルコール $73.7 \mathrm{~g}(1.6 \mathrm{~mol})$ およ゙ジメチ ホルムアミド8 $200 \mathrm{~g}(2.8 \mathrm{~mol})$ の混合物をかきむぜな゙ら $80^{\circ} \mathrm{C}$ で 10 時間反応させ, 冷却後反応混合物を水中に投入し，エーテ ル抽出して抽出液を無水硫酸マグネシウムで乾燥後, 上澄液を蒸

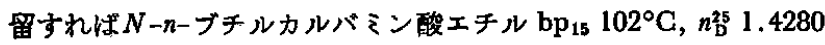
（文献值 $\left.\left.{ }^{9}\right) \mathrm{bp}_{15} 100^{\circ} \mathrm{G}, n_{\mathrm{D}}^{25} 1.4280\right) 24.4 \mathrm{~g}(86 \%)$ を得る。

\section{$2.2 N-n$-ブチルカルバミン酸-n-ブチル}

実験 2.1 においてエチルアルコールのかわりに $n$-ブチルアル コール $118.6 \mathrm{~g}(1.6 \mathrm{~mol})$ を用い, $100^{\circ} \mathrm{C}$ で 3 時間反応を行なわ

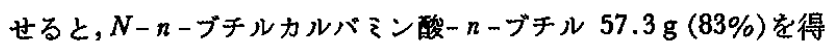
る。 $\mathrm{bp}_{4} 102^{\circ} \mathrm{C}, n_{\mathrm{D}}^{20} 1.4359$ (文献值 $\left.{ }^{10}\right) \mathrm{bp}_{3} 86^{\circ} \mathrm{C}, n_{\mathrm{D}}^{20} 1.4359$ )。

\section{$2.3 N$-n-プチルカルパミン賟ベンジル}

具化- $n$-ブチル $54.8 \mathrm{~g}(0.4 \mathrm{~mol})$, シアン酸 カリウム $40.5 \mathrm{~g}$ $(0.5 \mathrm{~mol})$, ベンジルアルコール $173 \mathrm{~g}(1.6 \mathrm{~mol})$ およびジメチル ホルムアミド $150 \mathrm{~g}(2.1 \mathrm{~mol})$ の混合物を $125^{\circ} \mathrm{C} て ゙ 5$ 時間反応さ せたのち冷却し，反応混合物を水中に投入し，ベンゼン抽出して 抽出液を乾燥後, 上澄液を蒸留すれば $N-n$-ブチルカルバミン酸 ベンジ， $\mathrm{bp}_{4} 147^{\circ} \mathrm{C}, n_{\mathrm{D}}^{20} 1.5085$ を $66.2 \mathrm{~g}(80 \%)$ 得る。

分析值 $\mathrm{N} 7.31 \%$

$\mathrm{C}_{11} \mathrm{H}_{15} \mathrm{O}_{2} \mathrm{~N}$ としての計算值 $\mathrm{N} 7.25 \%$

\section{$2.4 N$-n-プチルカルパミン酸-2-オキシエチル}

シアン酸カリウム $97.4 \mathrm{~g}(1.2 \mathrm{~mol})$, エチレングリコール 134.2 $\mathrm{g}(2.0 \mathrm{~mol})$ およびジメチルホルムアミド $500 \mathrm{~g}(6.8 \mathrm{~mol})$ の混合 物を $125^{\circ} \mathrm{C}$ に加熱して，かきまぜながら臭化- $n$-ブチル $137 \mathrm{~g}$

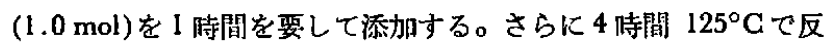
応をつづけたのち冷却し，反応混合物を口過して焦機塩を除去 したロ液を蒸留すれば $N$ - $n$-ブチルカルバミン酸-2-オキシエチ

9) "Beilstein Handbuch der Organische Chemie", 4, 158 (1944).

10) H. M. Curry, J. P. Mason, J. Am, Chem. Soc., 73, 5043 (1951). 
ル $98 \mathrm{~g}(61 \%)$ を得る。 $\mathrm{bp}_{12} 163^{\circ} \sim 164^{\circ} \mathrm{C}, n_{\mathrm{D}}^{20} 1.4562$ (文献值 ${ }^{11}$ ) $\mathrm{bp}_{13.5 \sim 14} 165^{\circ} \sim 166^{\circ} \mathrm{C}$ )。

\subsection{2-ビス $(\boldsymbol{N}-\boldsymbol{n}$-ブチルカルバモイルオキシ)エタン}

実験 2.4 において $N$-nーブチルカルバミン酸-2-オキシエチル を留去した残留物をソックスレ一抽出器に入れ，石油エーテルを 用いて抽出し，抵出液から石油エーテルを留去したのち，残留物を

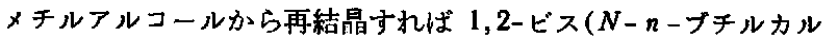
バモイルオキシ)エタン $36.3 \mathrm{~g}(28 \%)$ を得る。白色板状結晶, $\mathrm{mp}$ $106^{\circ} \sim 107^{\circ} \mathrm{G}$ で文献記载の方法により合成した標品(交献值 ${ }^{12}$ ) $\mathrm{mp}$ $106^{\circ} \mathrm{C}$ ) と混融しても融点降下を示さなかった。

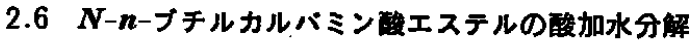

逆流冷却器付の $500 \mathrm{ml}$ フラスコに実験 2.1〜2.5 で得た $N-$ クーブテルカルバミン酸エステル $0.2 \mathrm{~mol}$ および $20 \%$ 塩酸 100 $\mathrm{ml}$ を入れて 6 時間薏沸したのち冷却する。反応混合物にフェ， 一ルフタレインを指示薬としてアルカリ性になるまで $50 \%$ 水酸 化カリウム水溶液を加え,逆流冷却管を留出管にかえて蒸留する。 留出液の一部分取して $1 \mathrm{~N}$ 塭酸で滴定し, また他の一部をとっ てガスクロマトグラフ法によって ーブチルアミンの取率を求め

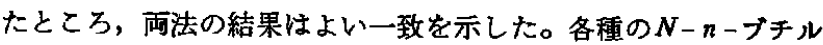
カルバミン酸エステルよりのnーブチルアミン収率を表 1 に示す。

\begin{tabular}{|c|c|}
\hline カルバミン酸エステル & $n-\mathrm{C}_{4} \mathrm{H}_{9} \mathrm{NH}_{2}$ 仅率 \\
\hline$n-\mathrm{C}_{4} \mathrm{H}_{9} \mathrm{NHCO}_{2} \mathrm{C}_{2} \mathrm{H}_{5}$ & 52 \\
\hline$n-\mathrm{C}_{4} \mathrm{H}_{9} \mathrm{NHCO}_{2} \mathrm{C}_{4} \mathrm{H}_{9}-n$ & 23 \\
\hline$n-\mathrm{C}_{4} \mathrm{H}_{9} \mathrm{NHCO}_{2} \mathrm{CH}_{2} \mathrm{C}_{8} \mathrm{H}_{5}$ & 43 \\
\hline$n-\mathrm{C}_{4} \mathrm{H}_{6} \mathrm{NHCO}_{2} \mathrm{CH}_{2} \mathrm{CH}_{2} \mathrm{OH}$ & 91 \\
\hline$\left(n-\mathrm{C}_{4} \mathrm{H}_{8} \mathrm{NHCO}_{2} \mathrm{CH}_{2}\right)_{2}$ & 83 \\
\hline
\end{tabular}

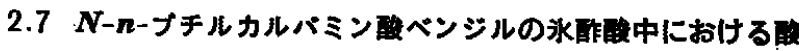
分解

$N$ - nーブチルカルバミン酸ベンジル $41.4 \mathrm{~g}(0.2 \mathrm{~mol})$ と氷酢酸 $200 \mathrm{ml}$ との混合溶液を $80^{\circ} \mathrm{C}$ に加熱し, 乾燥した㭚化水素を 4 時間にわたって吹き込む。反応混合物から氷酢酸を留去し, 得ら

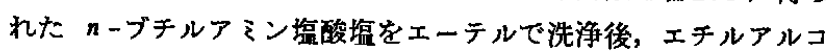
ールから再結晶すれば $\mathrm{mp} 195^{\circ} \mathrm{C}$ の純品が $18 \mathrm{~g}(82 \%)$ 德られ た。

\section{8 nーブチルアミン}

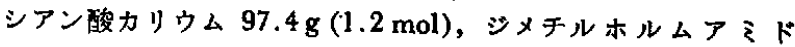
$500 \mathrm{~g}(6.8 \mathrm{~mol})$ およびェチレングリコール $134.2 \mathrm{~g}(2.0 \mathrm{~mol})$ の 混合物を $120^{\circ} \sim 125^{\circ} \mathrm{C}$ に加熱して，かきまぜながらこれに臭化一 ヘーブチル $137 \mathrm{~g}(1.0 \mathrm{~mol})$ を 1 時間を要して添加したのち, さら
に4 時間反応を行なわせて冷却する。反応混合物から無機塭を口 别したのち，口液を減压浱縮してジチルホルムアミドと末反応 のエチレングリコールの一部を除去する。浱縮物に $20 \%$ 㙁酸 $500 \mathrm{ml}$ を加え, 逆流冷却器を付したフラスコ中で 8 時間はげし く惹沸して加水分解を行なわせる。逆流冷却管の先端から窞和水 酸化バリウム水溶液中に導入される炭酸ガスの発生がほとんど見 られなくなったとき反店液を泠却し，50\% 水酸化カリウム水洛 液を添加してアルカり性にして蒸留する。水を含んだ $\boldsymbol{n}$ ーブチル アミンを固体水酸化ナトリウムでくり返し乾燥したのち,Widmer 分留管を用いて蒸留する。得られた $n$ ーブキルアミンは bp $77^{\circ}$ $\sim 78^{\circ} \mathrm{C}$ (文献值 ${ }^{13)} 77.8^{\circ} \mathrm{C}$ )で収量は $61 \mathrm{~g}(84 \%)$ であった。

\section{9 低被アルキルアミン}

実験 2.8 における真化-nーブチルのかわりに表 2 に示す其化ア ルキルを用いて同様の操作を行ない，それぞれ相当する第一ア ンを得た。なお具化一sーアルキルを使用した場合にはオレフィン の副生とイソシアヌル酸トリアルキルの多量の生成が認められ た。本法では $N$-アルキルカルバミン酸エステルからイソシアヌ ル酸エステルを除去することなく，反応混合物の浱縮物をそのま ま加水分解に付した。得られた結果は表 2 に示すとおりである。 各アルキルアミンはガスクロマトグラフ法により純品であること を確がめた。

表 2、低級アルキルアミンの合成

$\begin{array}{cccc}\text { 具化アルキル } & \text { アルキルアミン } & \text { 点 }\left({ }^{\circ} \mathrm{C}\right) & \text { 収率(\%) } \\ n-\mathrm{C}_{3} \mathrm{H}_{7} \mathrm{Br} & n-\mathrm{C}_{3} \mathrm{H}_{7} \mathrm{NH}_{2} & 46 \sim 48 & 91 \\ i-\mathrm{C}_{8} \mathrm{H}_{7} \mathrm{Br} & i-\mathrm{C}_{3} \mathrm{H}_{7} \mathrm{NH}_{2} & 31 \sim 33 & 40 \\ i-\mathrm{C}_{4} \mathrm{H}_{8} \mathrm{Br} & i-\mathrm{C}_{4} \mathrm{H}_{9} \mathrm{NH}_{2} & 67 \sim 68 & 82 \\ s-\mathrm{C}_{4} \mathrm{H}_{8} \mathrm{Br} & s-\mathrm{C}_{4} \mathrm{H}_{9} \mathrm{NH}_{2} & 62 \sim 63 & 34\end{array}$

\subsection{0 品稆アルキルアミン}

表 3 亿示す具化一 $n$-アルキル $0.25 \mathrm{~mol}$, シアン酸カリウム

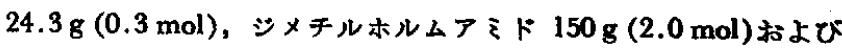
・エチレングリコール $31.0 \mathrm{~g}(0.5 \mathrm{~mol})$ の混合物をかきまぜながら $125^{\circ} \sim 130^{\circ} \mathrm{G}$ で 6 時間反応させたのち冷却する。反応混合物から 無譏程をロ別し，口液からジメチルホルムア ミドおよび末反応の エチレングリコールを減圧下で留去したのち,蒸留牫留物に $20 \%$ 塩酸 $300 \mathrm{ml}$ を加え，かきまぜながら 8 10 時間著沸する。冷却 後加水分解混合物に $50 \%$ 水酸化カリゥム水溶液を加えてアルカ リ性にしたのちベンゼン抽出する。抽出液を固体水酯化ナトリウ ムでくり返し乾嬠し，その上澄液をWidmer 分留管を用いて蒸 留すれば表 3 に示す結果を得る。各 $n$ ーアルキルアミンはフェニ ルオキサミドに誘導して確認した。

表 3 高級アルキルアミンの合成

\begin{tabular}{|c|c|c|c|c|c|c|}
\hline 莫化一 $n$-アルキル & nーアルキルアミン & 沸点 $\left({ }^{\circ} \mathrm{C}\right)$ & 融点 $\left({ }^{\circ} \mathrm{C}\right)$ & 収率 $(\%)$ & $\begin{array}{c}N->\simeq=ル-N^{\prime}- \\
\text { 酶点 }\left({ }^{\circ} \mathrm{C}\right)\end{array}$ & 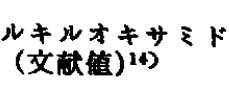 \\
\hline$n-\mathrm{C}_{8} \mathrm{H}_{13} \mathrm{Br}$ & $n-\mathrm{C}_{6} \mathrm{H}_{13} \mathrm{NH}_{2}$ & $131 \sim 133$ & - & 71 & $129 \sim 130$ & (130) \\
\hline$n-\mathrm{C}_{8} \mathrm{H}_{17} \mathrm{Br}$ & $n-\mathrm{C}_{8} \mathrm{H}_{17} \mathrm{NH}_{2}$ & $179 \sim 181$ & - & 68 & 126 & (126) \\
\hline$n-\mathrm{C}_{10} \mathrm{H}_{21} \mathrm{Br}$ & $n-\mathrm{C}_{10} \mathrm{H}_{21} \mathrm{NH}_{2}$ & $218 \sim 221$ & - & 69 & $121 \sim 122$ & (122) \\
\hline$n-\mathrm{C}_{12} \mathrm{H}_{25} \mathrm{Br}$ & $n-\mathrm{C}_{12} \mathrm{H}_{25} \mathrm{NH}_{2}$ & $257 \sim 260$ & 27 & 67 & $116 \sim 117$ & (117) \\
\hline$n-\mathrm{C}_{14} \mathrm{H}_{28} \mathrm{Br}$ & $n-\mathrm{C}_{14} \mathrm{H}_{29} \mathrm{NH}_{2}$ & $290 \sim 293$ & $36 \sim 37$ & 68 & - & - \\
\hline
\end{tabular}

11）小田良平，田状岩夫，日化，84，162(1963).

12) W. Kern, K. J. Rauterkus, W. Weber, W. Heitz,

13) A. Berg, Ann. chim. phys., [ 7 ]3, 292(1894). 


\subsection{1 アリルアミン}

シアン酸カリウム $200 \mathrm{~g}(2.4 \mathrm{~mol})$, ジチルホルムアミド 600 $\mathrm{g}(4.2 \mathrm{~mol})$ およびエチレングリコール $250 \mathrm{~g}(4.0 \mathrm{~mol})$ の混合物 をかきまぜながら $110^{\circ} \sim 115^{\circ} \mathrm{C}$ に加熱し，これに直化アリル $24.2 \mathrm{~g}(2.0 \mathrm{~mol})$ を 2 時間をかけて 滴下後なお 3 時間反応をつう けたのち泠却する。反応混合物から無譏塩を口別した口液を水浴 上で減圧洤縮してジチルホルムアミドと末反応のエチレングリ コールを除去したのち, 残留物にほほ等量の石油エーテルを加え $-10^{\circ} \mathrm{C}$ に冷却して1夜放置する。析出した結晶を口別してロ液 から石油エーテルを蒸発させた油状残留物を $20 \%$ 塩酸 $1 l$ 中に 投入して 10 時間煮沸する。得られた反応液を $50 \%$ 水酸化カリウ ム水溶液でアルカり性にして蒸留する。留出液を固体水酸化ナト リウムで乾燥後さらに金属ナトリウムで乾燥したのち分留すれば bp $55^{\circ} \sim 58^{\circ} \mathrm{C}$ (文献值 ${ }^{15)} \mathrm{bp}_{746} 57^{\circ} \mathrm{C}$ )のアリルアミン $108 \mathrm{~g}(65$ \%)を得る。このアリルアミンの合成において上記の水浴上で咸 圧沄縮した残留物の石油エーテル処理により得た結晶を減圧蒸留 すればイソシアヌル酸トリアリル( $\left.\mathrm{bp}_{6} 146^{\circ} \mathrm{C}, \mathrm{mp} 27^{\circ} \mathrm{C}\right)^{8)}$ が $27 \mathrm{~g}(25 \%)$ 得られた。アリルアミンはガスクロマトグラフ法によ り確認した。

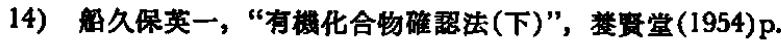
181 .

15) M. T. Leffler, "Organic Syntheses", (1943)Coll. Vol. 2, 24.

\subsection{2 メタリルアミン}

塩化メタリル $36.2 \mathrm{~g}(0.4 \mathrm{~mol})$, ンアン酸カリウム $40.5 \mathrm{~g}(0.5$ $\mathrm{mol})$, シメチルホルムア ₹ド $200 \mathrm{~g}(2.8 \mathrm{~mol})$ およびエチレング リコール $50 \mathrm{~g}(0.8 \mathrm{~mol})$ の混合物をかきまぜながら $90^{\circ} \sim 95^{\circ} \mathrm{C}$ で 5 時間反応させたのち冷却し，反応混合物家実呀 2.11 と同 じように処理すればメタリルアミン (bp $73^{\circ} \sim 79^{\circ} \mathrm{C}$, 文献值 ${ }^{16)}$ $\left.78.8^{\circ} \mathrm{C}\right)$ が $22.1 \mathrm{~g}(78 \%)$ 得られた。このメタリルアミンはガス タロマトグラフ法により確認した。

\subsection{3 ベンジルアミン}

実験 2.12 におて塩化メタリルのかわりに塩化ベンジル 50.6 $\mathrm{g}(0.4 \mathrm{~mol})$ を用いて $125^{\circ} \sim 130^{\circ} \mathrm{C}$ で 5 時間反応を行なわせる。 反応生成物から無機塩およびジチルホルムアミドを除去したの ち， $20 \%$ 塩酸 $200 \mathrm{ml}$ を加えて 8 時間竟沸して 加水分解する。 反応液に 50\% 水酸化カリウム水溶液を加えてアルカリ性にした のち蒸留し, 得られた含水ベンジルアミンをベンゼン抽出する。 抽出液を固体水酸化ナトリウムでくり返し乾燥後分留すれば38 $\mathrm{g}$

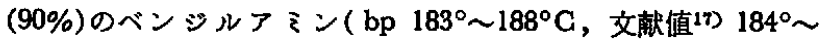

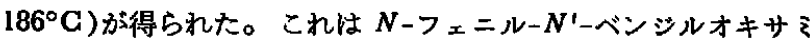
ド (mp $175^{\circ} \sim 176^{\circ} \mathrm{C}$, 交献值 $\left.\left.{ }^{16}\right) \mathrm{mp} 176^{\circ} \mathrm{G}\right)$ として確認された。

16) M. Tamele, C. J. Ott, K. E. Marple, G. Hearne, Ind. Eng. Chem., 33, 115(1941).

17) A. W. Ingersoll, "Organic Syntheses", (1943)Coll. Vol. 2, 503.

\section{アセト酢酸 2,4-ジニトロフェニルヒドラゾンの薄居クロマトグラフィー}

(昭和 40 年 12 月 13 日受理.)

保田道 子*1

アセト酶酸 2,4-ジニトロフェニルヒドラゾンには，ピルビン 酸その他の $\alpha$-ケト酸のヒドラシンン誘導体と同様，立体異性体 (syn 型と anti 型)存在の可能性がある。

しかし, 従来から行なわれているペーパークロマトグラフィ -1)-b)や, 薄層クロマトグラフィー日)の条件では，いずれる単一 のスポットしが得られず，異性体の存在は明らかでない。この点 を確かめるために，条件を変えて薄層クロマトグラフィーを試み たが，異性体に 相当する二つのスポットを分跳することができ た。

*1 Michiko YAsudA 大阪女子大学化学研究室, 大阪市住 吉区帝塚山

1) M. F. S. El Hawary, R. H. S. Thompson, Biochem. $J ., 53,340(1953)$.

2) S. Markees, ibid., 56, 703(1954).

3) A. M. Tokusige, E. S. Cook, Nature, 184, 267 (1959).

4) I. E. Bush, T. D. R. Hockaday, J. Chromatog., 8, 433 (1962).

5) 保田, 日化, 85, 449(1964).

6) J. Dancis, J. Hutzler, M. Levitz, Biochem, Biophys. Acta, 73, 85(1963).

\section{1 実験および結果}

試料: アセト酢酸 2,4-ジニトロフェニルヒドラゾンは既報了》 の方法によって得たものを用い，アセトンのヒドラゾンは，アセ

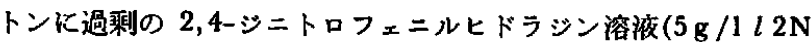
塭酸)を加えて生成したヒドラゾンをエタノールから再結晶した。 $\operatorname{mp} 124^{\circ} \sim 126^{\circ} \mathrm{C}$ 。

㖟菜绪: キーゼルゲルG(E. Merck)。

試絜: エタノール，アセトンは 1 級試薬を常法により精製，そ の他は市販特級試薬をそのまま使用した。

1.1 ヒドラン゙ンのアセトン溶浓の苚目クロマトグラフィー

展開: ブタノール:エタノール：水=4:2:1。

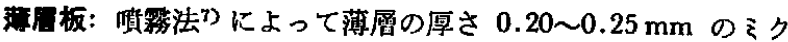
ロプレートをつくった。薄層に含まれる水分の量は，アセト眽酸 2,4-ジニトロフェニルヒドラゾンの二つのスポットの分蜼に大き な影響を与える。もっともよい結果が得られるのは含水量が 10 〜15\%の場合で，つぎのようにして水分の調節を行なった。1050

7) K. Morita, F. Haruta, J. Chromatog., 12, 412(1963). 